\title{
ANALISIS FAKTOR-FAKTOR YANG DIPERTIMBANGKAN KONSUMEN DALAM MENABUNG DI LEMBAGA KEUANGAN SYARIAH
}

\author{
Nihayatu Aslamatis Solekah
}

\author{
Fakultas Ekonomi Universitas Islam Negeri (UIN) Maliki Malang \\ Jl. Gajayana No. 50 Malang
}

Abstract

This paper aims to analyze the factors that considered by customer in making a decision to deposit their money at the Islamic Financial Institutions as well as to analyze the main factors considered by customers in making a decision to deposit in to Islamic Financial Institutions. The research method used is factor analysis. The analysis technique used is through the following stages: Description of Data, Test of variables Interdependence, extraction factor (early statistics), factor before the rotation, Rotation Factor and Validity Test and reliability of the model factor. The samples in this research are 100 respondents from 7 BMT in Malang city. Sampling of customers of Islamic financial institutions in this research is using a purposive sampling technique, which is sampling of customer of Islamic financial institution that intentional without consider the level in the population. This technique is done due to the member of the population is considered homogeneous and already well-known. The results of this study showed that environmental factors that consist of cultural, social class, personal, and family and marketing mix factors that consist of product, place, promotion, and price are the factors that considered by customers when making a decision to deposit their money in to Sharia Financial Institutions. The main factors to be considered are the marketing mix, and environmental factors.

Keywords: faktor lingkungan, faktor budaya, faktor kelas sosial, faktor stimulus pasar, keputusan menabung 
Di tengah rentannya kondisi keuangan global, perbankan syariah di Indonesia mencatatkan kinerja yang sangat bagus, baik secara kualitas maupun kuantitas. Menurut statistik Bank Indonesia, perkembangan dan pertumbuhan perbankan syariah di Indonesia setiap tahunnya cukup fantastis dan menggembirakan, tumbuh antara 40-45 persen per tahun. Hal ini tercermin dari pertumbuhan asset, peningkatan pembiayaan, ekspansi pelayanan (jaringan kantor yang semakin meluas menjangkau 33 propinsi di Indonesia). Sejak saat itu perkembangan bank-bank syariah di Indonesia terus semakin pesat dan menjamur. Terlebih lagi setelah ditetapkan UU No 10/1998 tentang Perubahan Undang-undang No 7 Tahun 1992 tentang Perbankan dan UU No 23/1999 tentang Bank Indonesia, telah memberikan peluang besar untuk pendirian kantor bank syariah baru atau mengkonversi bank konvensional menjadi Bank Syariah (Usahawan, 2000:4).

Hal yang sangat penting dari peraturan baru itu adalah bahwa bank-bank umum dan bank-bank perkreditan rakyat konvensional dapat menjalankan transaksi perbankan syariah melalui pembukaan kantor-kantor cabang syariah, atau mengkonversikan antor cabang konvensional menjadi kantor cabang syariah. Perangkat hukum itu diharapkan telah memberikan dasar hukum yang lebih kokoh dan peluang yang lebih besar dalam pengembangan perbankan syariah di Indonesia (Arifin, 2002:10)

Kalangan umat Islam sendiri secara emosional menunjukan antusiasmenya. Harapan menjalani hidup secara syariah dunia akhirat sudah di depan mata. Mereka dapat menjalankan ibadah dengan tenang, menghidupi keluarganya dengan rezeki yang halal. Sebab konsep syariah ini dikembangkan mengiringi kebutuhan sektor riil, yang melarang jual beli uang, spekulasi, dan tidak mengakui nilai mendatang. Ini semua bentuk riba menurut sistem syariah.

Umat Islam dilarang mengambil riba apapun jenisnya, larangan tersebut bersumber dari al Quran dan al Hadist, di antaranya adalah:

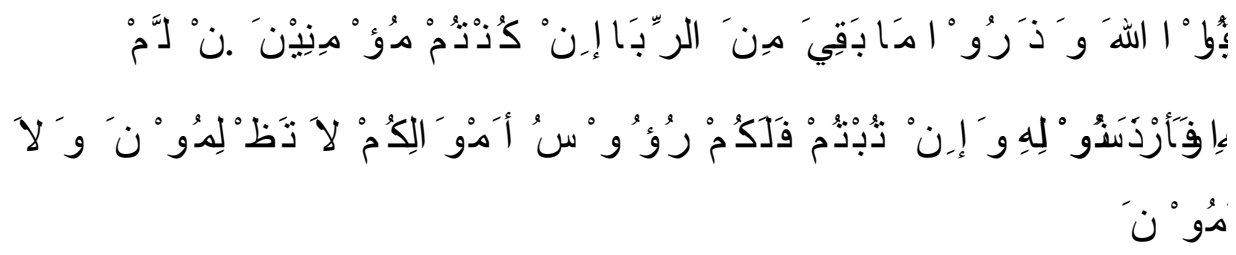

"Hai orang-orang yang beriman, bertaqwalah kepada Allah dan tinggalkan sisa riba (yang belum dipungut) jika kamu orang-orang yang beriman. Maka jika kamu tidak mengerjakan (meninggalkan sisa riba) maka ketahuilah bahwa Allah dan Rosulnya akan memerangimu. Dan jika kamu bertaubat (dari pengambilan riba) maka bagimu pokok hartamu; kamu tidak menganiaya dan tak pula dianiaya” (al Baqarah: 278-9) 
Adapaun hadits Nabi saw. yang menerangkan hal tersebut adalah:

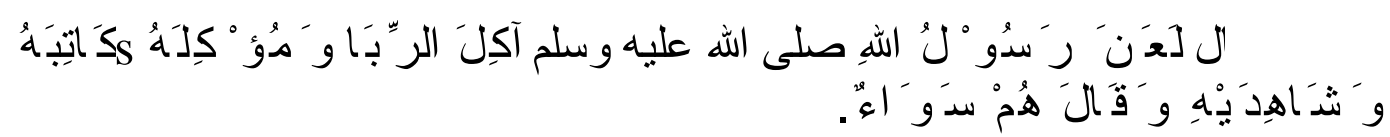

"Jabir berkata bahwa Rosulullah SAW mengutuk orang yang menerima riba, orang yang membayarnya dan orang yang mencatatnya, dan dua orang sakainya, kemudian beliau bersabda, Mereka itu semua sama” (HR Muslim).

Lembaga Keuangan Syariah sebagai sebuah bank pada awal berdirinya mempunyai tujuan untuk bisa bermuamalah dalam bidang ekonomi yang sesuai dengan syariat Islam, juga harus bersaing dengan bank lainnya untuk merebut nasabah. Akan tetapi yang menjadi permasalahan adalah motivasi dari nasabah di Lembaga Keuangan Syariah sangat beraneka ragam. Meskipun pada mulanya Lembaga Keuangan Syariah ingin mewadahi dan menampung masyarakat yang tidak setuju dengan sistem bunga bank konvensional, akan tetapi tidak menutup kemungkinan karena motivasi lainnya, seperti karena hanya faktor dekatnya letak bank tersebut dari tempat tinggal nasabah atau karena faktor pelayanan ataupun faktor lainnya. Dengan mengetahui motivasi dari nasabah tentunya hal ini akan bermanfaat bagi usaha untuk mengembangkan Lembaga Keuangan Syariah.

Oleh karena itu, maka peneliti akan berusaha melihat fenomena dan animo masyarakat dalam keputusannya untuk menabung di Lembaga Keuangan Syariah (dalam hal ini di Lembaga Keuangan Syariah BMT Perdana Surya Utama Malang). Penelitian ini mempunyai tujuan untuk menganalisis faktor-faktor apa sajakah yang dipertimbangkan konsumen dalam keputusan untuk menabung pada Lembaga Keuangan Syariah, serta untuk menganalisis faktor manakah dari faktor-faktor tersebut yang paling dipertimbangkan konsumen dalam keputusan untuk menabung pada Lembaga Keuangan Syariah.

Hasil penelitian ini diharapkan dapat memberikan manfaat sebagai untuk memberikan gambaran lebih jauh kepada para ilmuwan, peneliti, pembaca, dan masyarakat bahwa ada berbagai macam faktor yang dipertimbangkan konsumen dalam keputusan untuk menabung pada Lembaga Keuangan Syariah. Selain itu, sebagai bahan pertimbangan pihak Lembaga Keuangan Syariah di dalam mengembangkan sistem bagi hasil serta untuk memberikan gambaran kepada pihak-pihak yang berminat untuk mengembangkan Bank Islam tentang pemahaman masyarakat selama ini tentang bank.

Dalam penelitian ini penulis hanya meneliti minat nasabah/konsumen secara individual saja, tidak dengan konsumen industri. Untuk menyederhanakan masalah peneliti hanya memilih faktor-faktor berdasarkan penelitian terdahulu dengan menambahkan faktor-faktor yang diduga dipertimbangkan oleh nasabah/konsumen dalam keputusan untuk menabung di Lembaga Keuangan Syariah Baitul Maal wa 
Tamwil Perdana Surya Utama. Karena luasnya asumsi yang dapat diambil dari teori dan kondisi riil obyek penelitian maka penelilti hanya menyoroti pada faktor lingkungan (sosial budaya) dan faktor stimuli pemasaran.

\section{TINJAUAN PUSTAKA}

\section{Pengertian BMT}

Baitul maal wa Tamwil berasal dari bahasa arab disingkat menjadi BMT adalah kelompok swadaya masyarakat (KSM) sebagai lembaga ekonomi rakyat yang berupaya mengembangkan usaha-usaha produktif dan investasi dengan sistem bagi hasil untuk meningkatkan kualitas kegiatan ekonomi pengusaha kecil dan dalam rangka upaya pengentasan kemiskinan. Kegiatan BMT mengembangkan usahausaha produktif dan investasi dalam meningkatkan kualitas kegiatan ekonomi pengusaha makro dan kecil untuk mendorong kegiatan menabung dan menunjang pembiayaan kegiatan ekonominya, sedangkan kegiatan Baitul maal menerima titipan BAZIS dari dana zakat, infaq, dan shodaqoh dan menjalankannya sesuai dengan peraturan dan amanahnya.

Dalam definisi operasional PINBUK (1998:2) BMT adalah lembaga usaha ekonomi rakyat kecil, yang beranggotakan orang seorang atau berbadan hukum berdasarkan prinsip syariah dan prinsip koperasi. Secara mendasar prinsip-prinsip operasional lembaga keuangan islam atau bank syariah dapat dilukiskan sebagaimana gambar 1.

\section{Model Perilaku Konsumen Howard-Sheth}

Pembahasan perilaku konsumen dalam sebuah model yang menyeluruh telah diusulkan oleh Howard pada tahun 1963. Tetapi model ini baru dipublikasikan dalam buku "The Theory of Buyer Behavior" di tahun 1969 oleh John A Howard dan Jagdish N. Sheth, sehingga lebih dikenal sebagai model Howard-Sheth (Howard dan Sheth, 1969:254). Model tersebut dapat dipakai untuk membantu dalam menerangkan dan memahami perilaku konsumen meskipun tidak dapat meramalkannya secara tepat.

Agar suatu input tertentu bias menghasilkan suatu output yang tertentu pula, maka diperlukan adanya informasi dan proses pengambilan keputusan yang melibatkan motivasi, persepsi dan proses belajar seseorang. Model Howard-Sheth tentang perilaku konsumen berisi empat elemen pokok yaitu: (1) Input (variable rangsangan/stimuli), (2) Susunan Hipotesis (hypothetical constructs), (3) Output (response variables), (4) Variabel-variabel Eksogen (Exogeneous variables). 


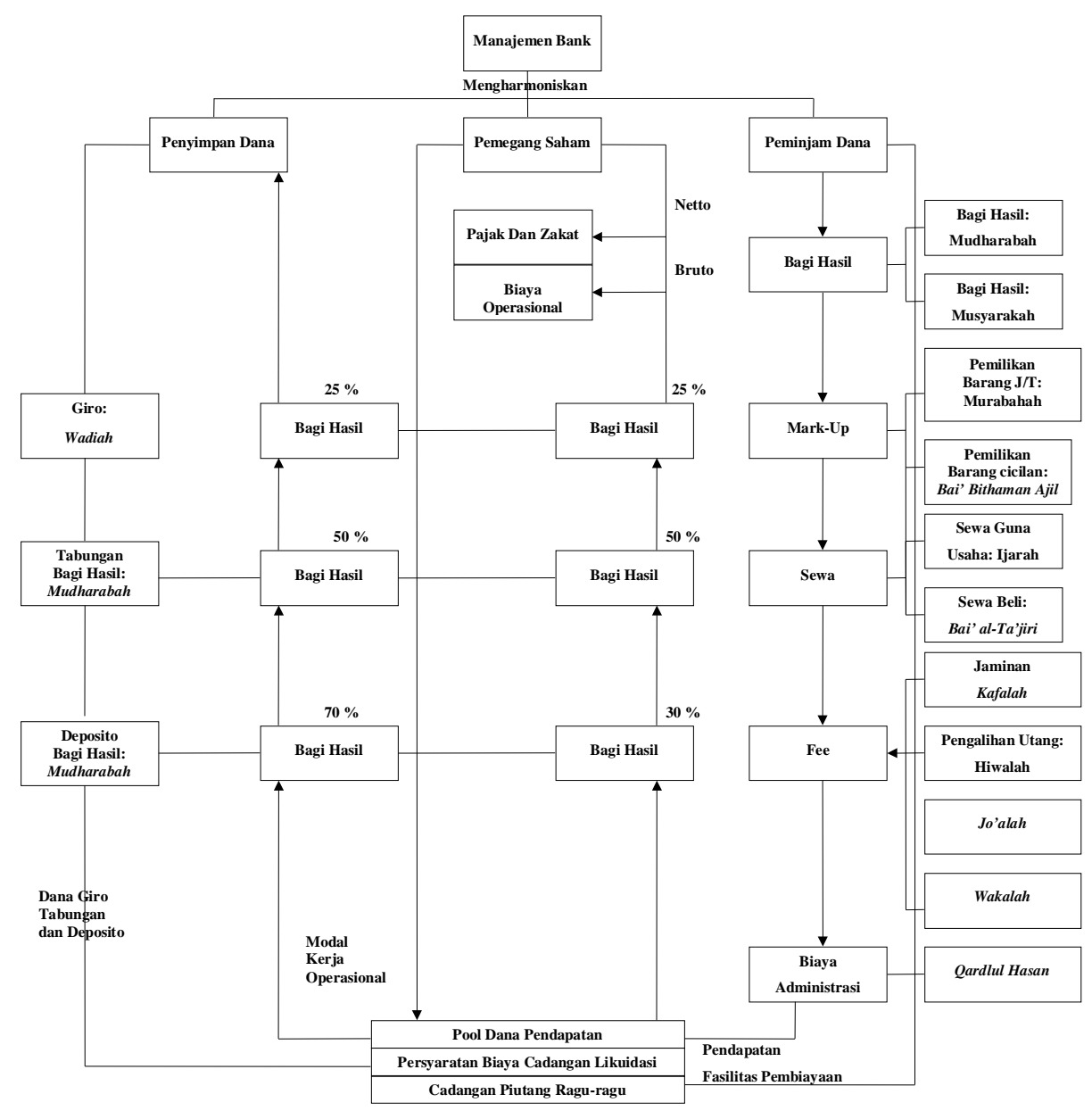

Gambar 1. Prinsip-Prinsip Operasional LKS

Sumber: Muhammad (2001:75)

\section{Faktor-Faktor yang Mempengaruhi Perilaku Konsumen}

Salah satu hal penting untuk memahami perilaku konsumen dalam pengambilan keputusan pemilihan produk atau jasa yang akan memuaskan kebutuhan mereka adalah dengan memahami kaarakteristik dari konsumen itu sendiri. Faktor-faktor utama yang mempengaruhi perilaku konsumen menurut Kotler adalah faktor budaya, sosial, kepribadian dan psikologi (Kotler, 1997:153).

\section{Pengaruh Lingkungan}

Menurut angel lingkungan yang terdiri dari budaya, kelas sosial, pengaruh pribadi, keluarga dan situasi dapat mempengaruhi proses keputusan konsumen, sebagaimana gambar 4. 


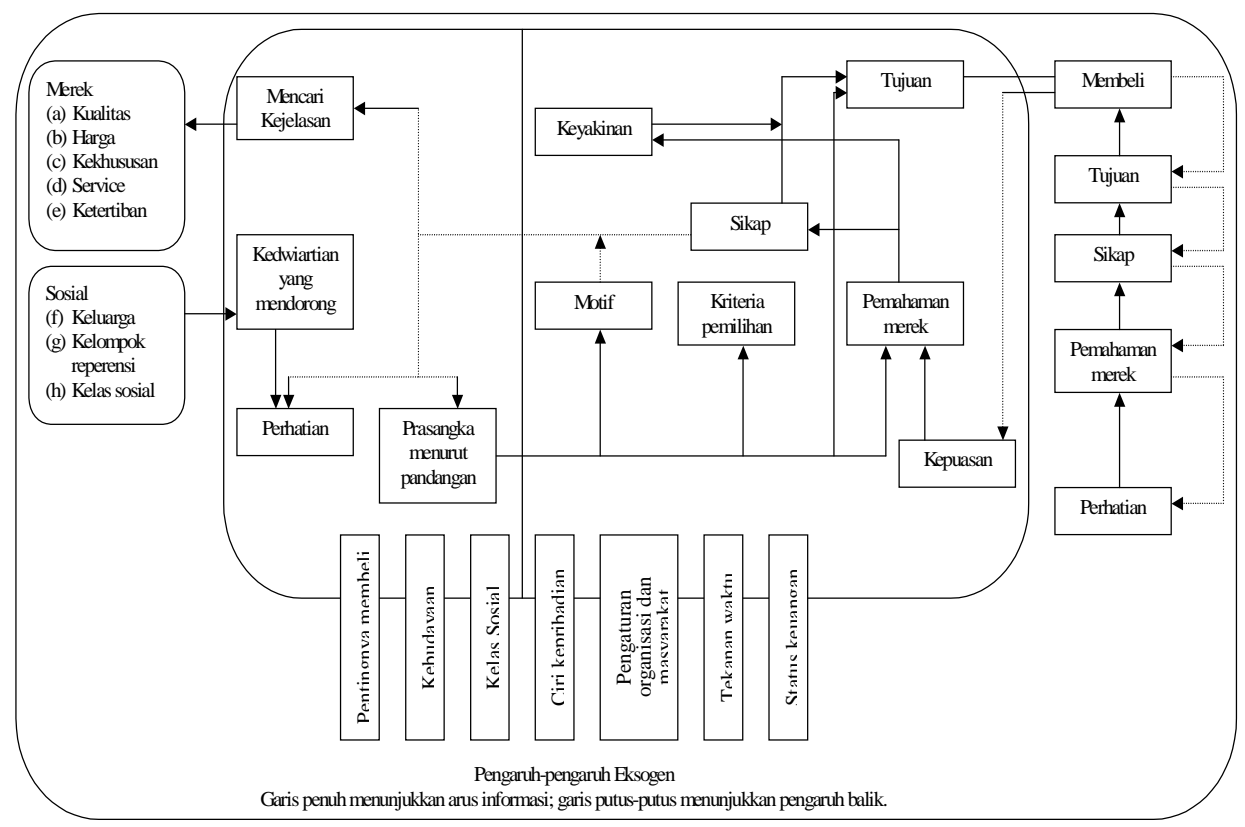

Gambar 2. Model Perilaku Pembelian Konsumen dari Howard - Sheth

Sumber: dikutip oleh Swasta dan Handoko (1994:41)

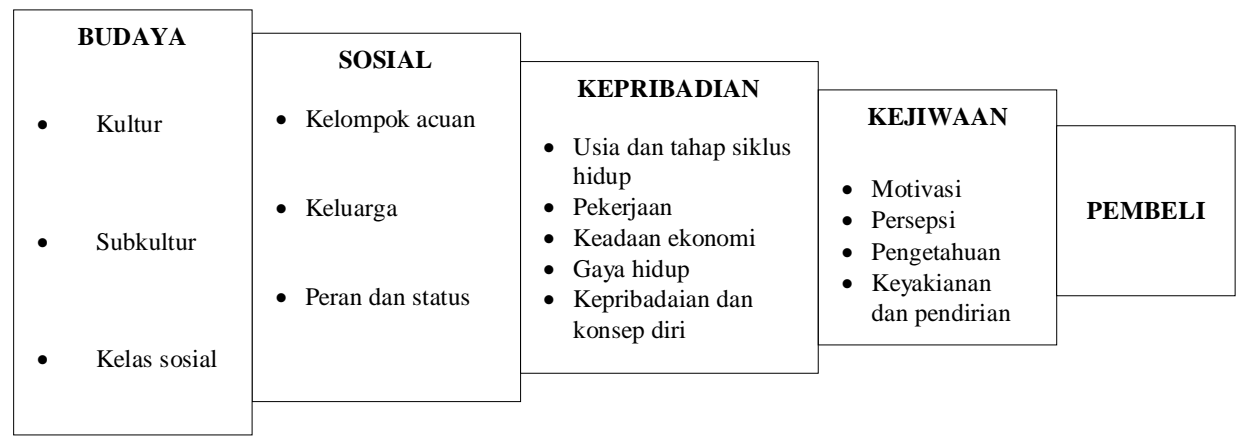

Gambar 3. Faktor-Faktor yang Mempengaruhi Perilaku Konsumen

Sumber: Kotler, (1997: 153)

\section{Pengaruh Stimuli Pemasaran}

Stimuli Pemasaran adalah semua usaha yang dilakukan oleh pemasar untuk mempengaruhi perilaku konsumen ataupun berupa umpan balik dari konsumen yang diaplikasikan dalam strategi pemasaran. Kotler (1997:50) mengungkapkan bauran pemasaran yaitu: "Perangkat alat pemasaran taktis yang dapat dikendalikan, yang diperlukan oleh perusahaan untuk menghasilkan respon yang diinginkan dalam pasar sasaran". 


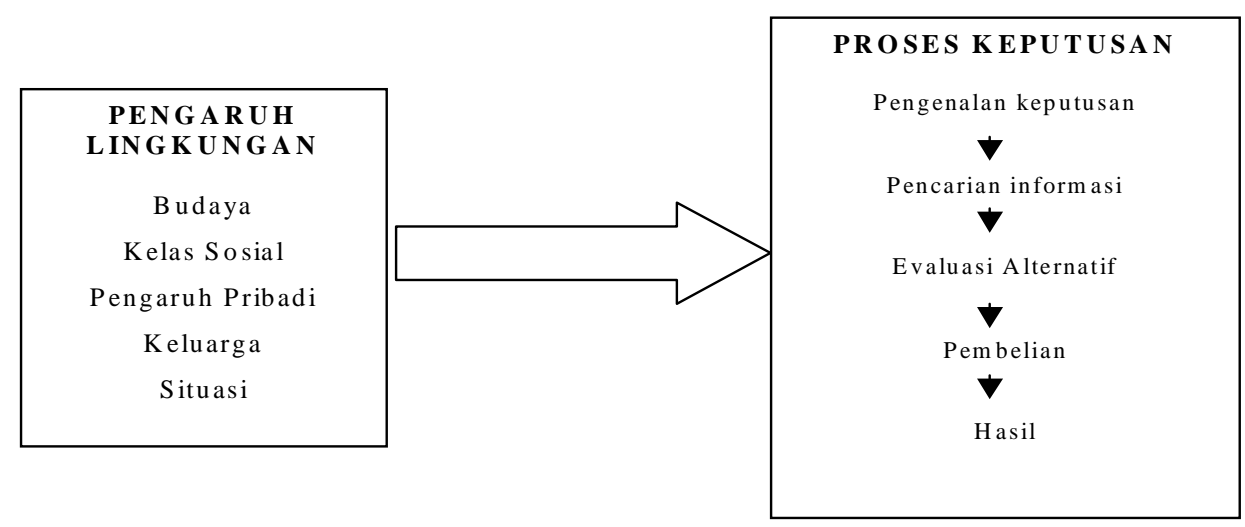

\section{Gambar 4. Pengaruh Lingkungan pada Perilaku Konsumen}

Sumber: Angel, et al. (1994:47)

Bauran pemasaran terdiri dari segala sesuatu yang dapat dilakukan pemasar untuk mempengaruhi permintaan produknya. Kemungkinan yang banyak itu dapat dikelompokkan ke dalam empat variabel yang dikenal sebagai "empat P" yaitu : Product, Price, Place dan Promotion.

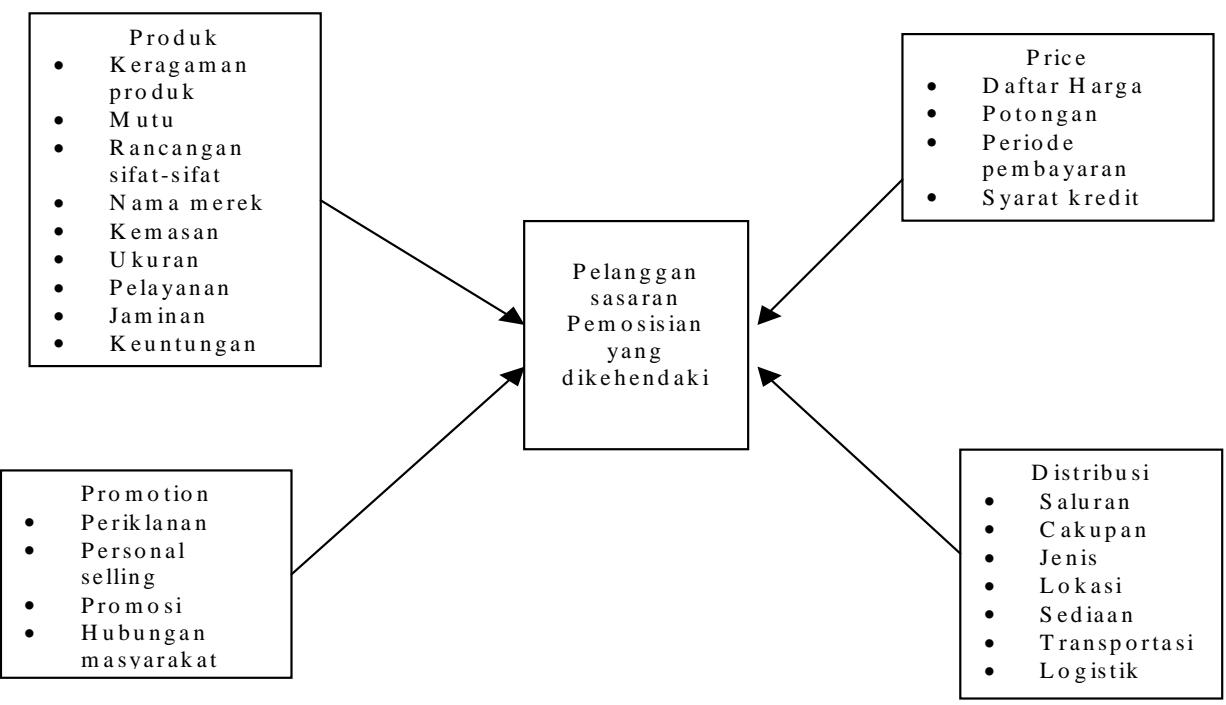

Gambar 5. Empat P dari Bauran Pemasaran

Sumber: Prabu (1988:45)

\section{Hipotesis}

Hipotesis merupakan suatu anggapan sementara yang masih harus dibuktikan kebenarannya, dan dalam penelitian ini anggapan sementara adalah bahwa konsumen dalam keputusannya untuk menabung mempertimbangkan faktor lingkungan (sosial budaya) dan stimuli pemasaran. Diduga bahwa faktor lingkungan (sosial 
budaya) dan faktor stimuli pemasaran dipertimbangkan konsumen dalam keputusan untuk menabung di Lembaga Keuangan Syariah. Diduga faktor agama (lingkungan) paling dipertimbangkan konsumen dalam keputusan untuk menabung di Lembaga Keuangan Syariah.

Dalam penelitian ini, sesuai dengan penelitian terdahulu peneliti mengambil hipotesa bahwa faktor yang paling dipertimbangkan adalah larangan agama terhadap riba (faktor lingkungan budaya).

\section{Kerangka Pemikiran Penelitian}

Pengaruh Lingkungan (X1)

- Budaya

Larangan agama tentang

bunga bank (X11)

Sistem bagi hasil sesuai syariat (X12)

- Kelas sosial Anjuran Ulama/tokoh (X13)

- $\quad$ Pengaruh Pribadi Mengamalkan syariat Islam (X14)

- Keluarga Pengaruh keluarga atau kerabat dekat (X15)
Stimuli Pemasaran(X2)

- Product

Jenis produk yang bervariasi (X21)

Jenis produk yang sesuai dengan kebutuhan (X22)

layanan yang cepat dan ramah (X23)

- Place

Lokasi bank yang strategis dan mudah dijangkau (X24)

Lokasi bank dekat dengan rumah (X25)

- Promotion

Pengaruh brosur atau personal selling (X26)

- $\quad$ Price

Nisbah bagi hasil yang tinggi (X27)

Jaminan keamanan uang (X28)

\section{Gambar 6. Model Kerangka Pikir Penelitian}

\section{Alat Analisis}

Berdasarkan permasalahan maka alat analisa yang kami gunakan adalah analisis faktor. Alasan menggunakan teknik analisis ini adalah karena jenis data yang terkumpul berupa data interval. Sebagaimana dikemukakan Tuckman (1972:229), bahwa dasar untuk menentukan uji statistik dengan mempertimbangkan jenis data interval lebih dari satu untuk variabel independent (bebas) dengan jenis data yang sama untuk variabel dependent (terikat) adalah analisis faktor.

Model dari analisa faktor yang digunakan untuk menganalisis data dalam penelitian ini adalah sebagai berikut (Malholtra, 1993:619): 
$\mathrm{Y}_{\mathrm{i}}=\mathrm{A}_{\mathrm{i}} 1 \mathrm{~F} 1+\mathrm{A}_{\mathrm{i}} 2 \mathrm{~F} 2+\mathrm{A}_{\mathrm{i}} 3 \mathrm{~F} 3+\ldots+\mathrm{A}_{\mathrm{i}} \mathrm{mFm}+\ldots+\mathrm{V}_{\mathrm{i}} \mathrm{U}_{\mathrm{I}}$

Di mana:

$\mathrm{X}_{\mathrm{i}}=$ standarisasi variabel ke I

$\mathrm{A}_{\mathrm{ij}}=$ standarisasi koifisien regresi berganda variabel I pada faktor umum (common factor) $j$

$F \quad=$ faktor umum (common factori)

$\mathrm{V}_{\mathrm{i}}=$ standarisasi koifien regresi dari variabel i pada faktor khusus

$\mathrm{U}_{\mathrm{i}}=$ faktor khusus bagi variabel $\mathrm{i}$

$\mathrm{m}=$ jumlah dari faktor-faktor umum

\section{METODE, HASIL DAN PEMBAHASAN}

\section{Karakteristik Demografis Responden}

Hasil penelitian karaketristik responden dapat dilihat pada tabel 1 dan grafik 1 di bawah ini:

Tabel 1. Jumlah Responden Berdasarkan Usia

usia nasaoan

\begin{tabular}{|c|c|c|c|c|c|}
\hline & & Frequency & Percent & $\begin{array}{c}\text { Valid } \\
\text { Percent }\end{array}$ & $\begin{array}{c}\text { Cumulative } \\
\text { Percent }\end{array}$ \\
\hline \multirow[t]{7}{*}{ Valid } & $>40$ & 3 & 3.0 & 3.0 & 3.0 \\
\hline & $36-40$ & 8 & 8.0 & 8.0 & 11.0 \\
\hline & $26-30$ & 14 & 14.0 & 14.0 & 25.0 \\
\hline & $31-35$ & 17 & 17.0 & 17.0 & 42.0 \\
\hline & $<20$ & 27 & 27.0 & 27.0 & 69.0 \\
\hline & $20-25$ & 31 & 31.0 & 31.0 & 100.0 \\
\hline & Total & 100 & 100.0 & 100.0 & \\
\hline
\end{tabular}

usia nasabah

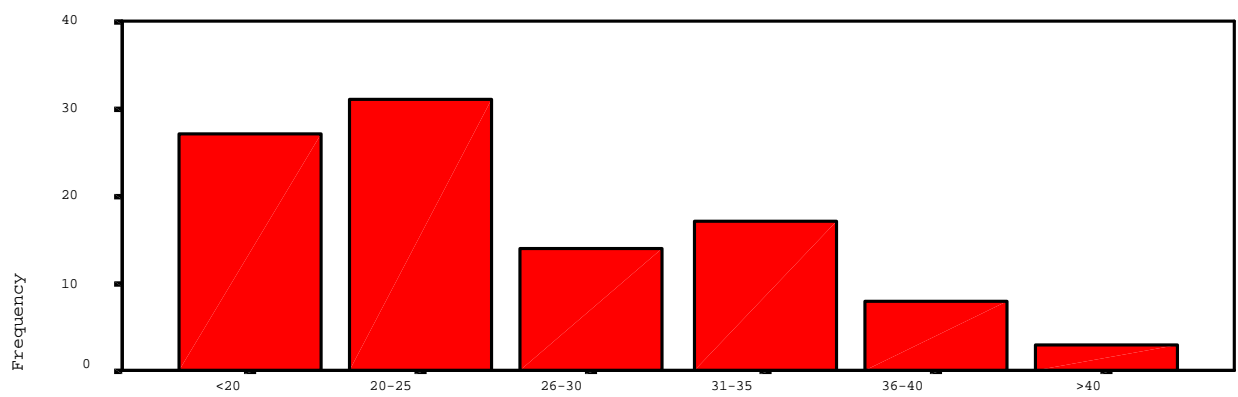

usia nasabah

\section{Grafik 1. Distribusi Usia Responden}

\section{Jenis Kelamin}

Distribusi responden menurut jenis kelamin dapat digambarkan dalam tabel 2 dan grafik 2 berikut ini: 
Tabel 2. Jumlah Responden berdasarkan Jenis Kelamin

jenis kelamin nasabah

\begin{tabular}{|r|r|r|r|r|}
\hline & Frequency & Percent & $\begin{array}{c}\text { Valid } \\
\text { Percent }\end{array}$ & $\begin{array}{c}\text { Cumulative } \\
\text { Percent }\end{array}$ \\
\hline Valid wanita & 42 & 42.0 & 42.0 & 42.0 \\
pria & 58 & 58.0 & 58.0 & 100.0 \\
Total & 100 & 100.0 & 100.0 & \\
\hline
\end{tabular}

jenis kelamin nasabah

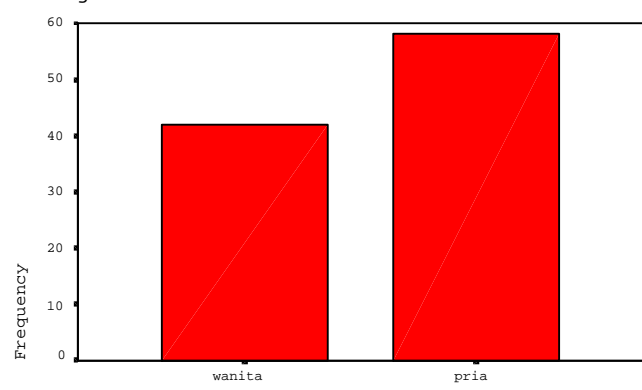

jenis kelamin nasabah

Grafik 2. Prosentase Responden Berdasarkan Jenis Kelamin

\section{Pekerjaan}

Distribusi responden menurut jenis pekerjaan dapat digambarkan dalam tabel 3 dan grafik 3 berikut ini:

Tabel 3. Jumlah Responden Berdasarkan Pekerjaan

pekerjaan nasabah

\begin{tabular}{|l|r|r|r|r|}
\hline & & & Valid & Cumulative \\
Percency & Percent & Percent & Percent \\
\hline Valid PNS/TNI & 2 & 2.0 & 2.0 & 2.0 \\
wiraswasta & 12 & 12.0 & 12.0 & 14.0 \\
ibu rumah tan & 12 & 12.0 & 12.0 & 26.0 \\
pegawai swast & 22 & 22.0 & 22.0 & 48.0 \\
pelajar & 25 & 25.0 & 25.0 & 73.0 \\
mahasiswa & 27 & 27.0 & 27.0 & 100.0 \\
Total & 100 & 100.0 & 100.0 & \\
\hline
\end{tabular}




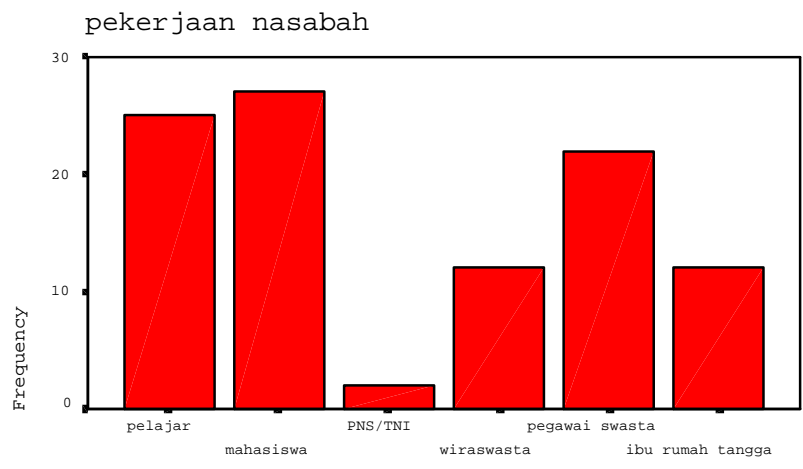

\section{Grafik 3. Jenis Pekerjaan}

\section{Tingkat Pendidikan}

Distribusi responden berdasarkan pendidikan terakhir dapat digambarkan dalam tabel 4 dan grafik 4 berikut ini:

Tabel 4. Jumlah Responden BerdasarkanTingkat Pendidikan Akhir pendidikan terakhir

\begin{tabular}{|ll|r|r|r|r|}
\hline & Frequency & Percent & $\begin{array}{c}\text { Valid } \\
\text { Percent }\end{array}$ & $\begin{array}{c}\text { Cumulative } \\
\text { Percent }\end{array}$ \\
\hline Valid SD & 5 & 5.0 & 5.0 & 5.0 \\
& 20 & 20.0 & 20.0 & 25.0 \\
SMP & 48 & 48.0 & 48.0 & 73.0 \\
SMU & 24 & 24.0 & 24.0 & 97.0 \\
Sarjana & 3 & 3.0 & 3.0 & 100.0 \\
lain-lain & 100 & 100.0 & 100.0 & \\
Total & &
\end{tabular}

pendidikan terakhir

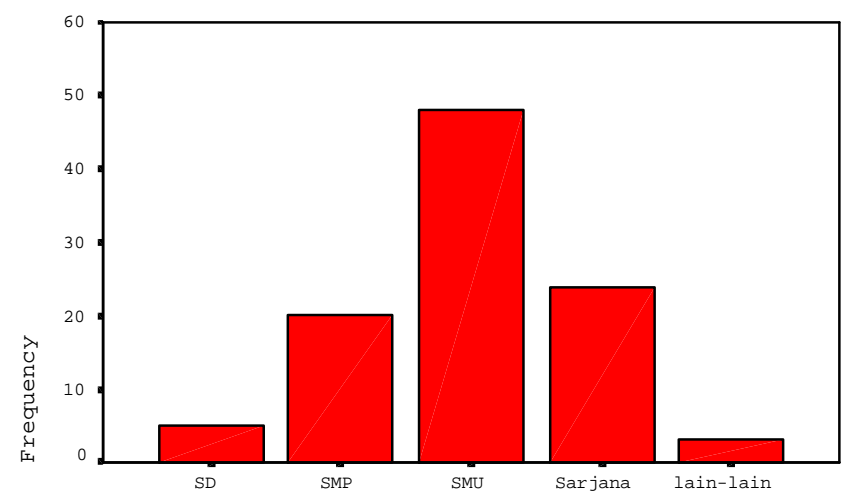

pendidikan terakhir

\section{Grafik 4. Tingkat Pendidikan}

El-Dinar, Vol. 1, No 1, Januari 2013 


\section{Analisis Faktor}

Pengujian awal interdependensi variabel-variabel adalah pengukuran kecukupan sampling (Measure of sampling adequacy atau MSA) melalui korelasi anti image. Nilai MSA terdapat pada nilai-nilai yang ditunjukkan pada bagian diagonal matriks korelasi anti-image. MSA merupakan indeks yang dimiliki setiap variabel yang menjelaskan apakah sampel yang diambil dalam penelitian cukup untuk membuat variabel-variabel yang ada saling terkait secara parsial. Variabel yang memiliki MSA kecil $(<0,5)$ dikeluarkan dari analisis. Hal ini bisa dilihat dari tabel dibawah ini:

Tabel 5. Nilai Measures of Sampling Adequacy Pertama

\begin{tabular}{lc}
\hline \multicolumn{1}{c}{ Variabel } & Nilai MSA \\
\hline X11 (Larangan agama tentang bunga bank) & 0,771 \\
X12 (sistem bagi hasil yg sesuai syariat) & 0,630 \\
X13 (Anjuran Ulama/kelompok keagamaan) & 0,732 \\
X14 (Mengamalkan syariat islam) & 0,489 \\
X15 (Pengaruh keluarga/kerabat dekat) & 0,711 \\
X21 (Jenis tabungan yang bervariasi) & 0,530 \\
X22 (Jenis tabungan sesuai dengan kebutuhan) & 0,546 \\
X23 (layanan cepat dan ramah) & 0,635 \\
X24 (Lokasi bank yg strat egis \& mudah dijangkau) & 0,477 \\
X25 (Lokasi bank dekat dengan tempat tinggal) & 0,612 \\
X26 (Personal selling/brosur) & 0,840 \\
X27 (Nisbah bagi hasil yang tinggi) & 0,800 \\
X28 (Jaminan keamanan uang) & 0,509 \\
\hline
\end{tabular}

\section{Uji Validitas dan Reliabilitas Model Faktor}

Dari hasil uji reliabilitas model faktor pada tabel 6, dapat disimpulkan bahwa 3 model faktor adalah reliabel, artinya analisis faktor dapat dihandalkan atau dapat memberikan hasil model faktor yang tidak berbeda bila dilakukan pengukuran kembali terhadap subyek yang sama.

Tabel 6. Hasil Uji Reliabilitas Model Faktor

\begin{tabular}{|c|c|c|c|c|c|c|}
\hline Faktor & Var & komunalitas & $h^{2}$ & $\begin{array}{c}\text { Koef } \\
\text { reliabilitas }\end{array}$ & $\begin{array}{c}\text { Koef } \\
\text { pembanding }\end{array}$ & Ket \\
\hline \multirow{4}{*}{ Faktor 1} & $\mathrm{X} 22$ & 0,674 & 0,638 & 0,876 & 0,5 & $\overline{\text { reliabel }}$ \\
\hline & $\mathrm{X} 21$ & 0,639 & & & & \\
\hline & $\mathrm{X} 28$ & 0,603 & & & & \\
\hline & $\mathrm{X} 25$ & 0,635 & & & & \\
\hline \multirow[t]{2}{*}{ Faktor 2} & $\mathrm{X} 12$ & 0,690 & 0,659 & 0,794 & 0,5 & reliabel \\
\hline & $\mathrm{X} 11$ & 0,628 & & & & \\
\hline \multirow[t]{2}{*}{ Faktor 3} & $\mathrm{X} 15$ & 0,651 & 0,651 & 0,789 & 0,5 & reliabel \\
\hline & $\mathrm{X} 13$ & 0,652 & & & & \\
\hline
\end{tabular}




\section{Interpretasi Faktor}

Interpretasi faktor mengacu pada hasil analisis yang telah diringkas pada tabel 6, pada tabel tersebut tampak bahwa 8 variabel yang ada tersebar pada 3 faktor dengan total varian (cummulative percentage) sebesar $64,657 \%$ dan dengan kisaran factor loading antara 0,621 hingga 0,815. Faktor utama yang menduduki rangking tertinggi yang dipertimbangkan konsumen dalam keputusan untuk menabung di lembaga keuangan syariah yaitu faktor stimuli pemasaran. Faktor kedua yang dipertimbangkan konsumen dalam keputusan untuk menabung di lembaga keuangan syariah yaitu Faktor Lingkungan. Faktor ketiga yang dipertimbangkan konsumen dalam keputusan untuk menabung di lembaga keuangan syariah yaitu faktor lingkungan

\section{Pembuktian Hipotesis}

\section{Hipotesis Pertama}

Hipotesis pertama disebutkan bahwa keputusan untuk menabung di lembaga keuangan syari' ah oleh konsumen secara bersama-sama mempertimbangkan faktorfaktor lingkungan (sosial budaya) dan faktor stimuli pemasaran. Stimuli pemasaran didukung oleh variabel-variabel jenis tabungan yang sesuai kebutuhan, jenis tabungan yang bervariasi, jaminan keamanan uang, dan lokasi bank dekat dengan tempat tinggal, Faktor lingkungan didukung oleh variabel-variabel pengaruh keluarga, dan anjuran ulama/kelompok keagamaan. Faktor lingkungan. didukung oleh variabelvariabel sistem bagi hasil yang sesuai syariah dan larangan agama tentang bunga bank. Dari hasil analisis faktor, hipotesis yang pertama telah terbukti yaitu terdapat sumbangan faktor-faktor lingkungan (sosial budaya) dan faktor stimuli pemasaran. yang dipertimbangkan konsumen dalam keputusan untuk menabung di lembaga keuangan syari'ah.

\section{Hipotesis Kedua}

Hipotesis kedua disebutkan bahwa faktor lingkungan merupakan faktor utama yang dipertimbangkan konsumen dalam keputusan untuk menabung di di lembaga keuangan syari'ah. Hipotesis kedua ini tidak terbukti sebab dari hasil penelitian, faktor lingkungan merupakan faktor dengan urutan ke-2 dan ke-3.

\section{KESIMPULAN DAN SARAN}

\section{Kesimpulan}

Faktor utama yang menduduki rangking tertinggi yang dipertimbangkan konsumen dalam keputusan untuk menabung di Lembaga Keuangan Syariah yaitu Faktor stimuli pemasaran. Faktor kedua yang dipertimbangkan konsumen dalam keputusan 
untuk menabung di Lembaga Keuangan Syariah yaitu Faktor Lingkungan. Hipotesis pertama disebutkan bahwa keputusan untuk menabung di lembaga keuangan syariah oleh konsumen secara bersama-sama mempertimbangkan faktor-faktor lingkungan (sosial budaya) dan faktor stimuli pemasaran. Faktor stimuli pemasaran didukung oleh variabel-variabel jenis tabungan yang sesuai dengan kebutuhan, jenis tabungan yang bervariasi, jaminan keamanan uang dan lokasi bank dekat dengan tempat tinggal. Faktor Lingkungan didukung oleh variabel-variabel pengaruh keluarga, dan anjuran ulama/kelompok keagamaaan. Demikian pula didukung variabel sistem bagi hasil yang sesuai syariah dan larangan agama tentang bunga bank.

\section{Saran}

Diperlukan adanya peningkatan pemasaran pada personal selling dan promosi, sebab dari hasil penelitian ini nasabah masih belum merasakan pengaruhnya meskipun pihak bank telah melakukan pemasaran melalui dua cara tersebut. Hendaknya pihak manajer mempertahankan tradisi mengadakan kajian-kajian keagamaan, sebab meskipun larangan bunga bank itu haram bukan menjadi prioritas nasabah, namun ternyata tingkat kesadaran nasabah mulai meningkat dengan adanya kajian-kajian keagamaan atau sosialisasi kegamaan dari tokoh ulama. Peningkatan sumber daya insani pada pelayanan nasabah, apakah tabungan maupun kredit dengan disertai peningkatan mutu peralatan yang lebih bagus dari yang sekarang

\section{DAFTAR PUSTAKA}

Antonio, S.M. 2001. Bank Syariah dari Teori ke Praktik, Jakarta: Gema Insani Press.

Arifin, Z. 1999. Memahami Bank Syariah, Lingkup, Peluang, Tantangan dan Prospek. Jakarta: Alvabet. 2002.Dasar-dasar Manajemen Bank Syariah. Jakarta: Alvabet.

Engel, James, F., Roger, D.B., and Paul, W.M. 1994. Perilaku konsumen, Terjemahan Budianto. Jakarta. Binarupa Aksara.

Kahf, M. 1995. Ekonomi Islam, Telaah analitik terhadap Fungsi Sistem Ekonomi Islam. Yogyakarta: Penerbit Pustaka Belajar.

Kotler, P. 1997. Manajemen Pemasaran : Analisis, Perencanaan, Implementasi, dan kontrol (edisi Indonesia), terj Hendra Teguh, Rony Antonious Rusli. Jakarta: Prenhallindo.

Malhotra, Naresh, K. 1996, Marketing Research: An Aplied Orientation. Prentice Hall International, inc, New Jersey.

Marzuki. 1997. Metodologi Riset, Yogyakarta: BPFE UII.

Muhammad. 2000. Lembaga-lembaga keuangan Umat Kontemporer. Yogyakarta: UII Press. Nasir, M. 1988. Metode Penelitian. Jakarta: Ghalia Indah.

Qordhowi, Y. Terj Zainal Arifin \& Dahlia Husin. 1997. Norma dan Etika Ekonomi Islam. Jakarta: Gema Insani Press.

Prabu, M.A.A., Anwar. 1988. Perilaku Konsumen, cetakan pertama. Bandung: PT Eresco. 
Santoso, S., Tjiptono. 2001. Riset Pemasaran, Konsep Aplikasi dengan SPSS. Jakarta: Penerbit PT Alex Media Komputindo Kelompok Gramedia.

Siamat, D. 1999. Manajemen Lembaga Keuangan. Jakarta: LPFE UI.

Singarimbun, M., Sofian, E. 1989, Metode Penelitian Survai. Jakarta: LP3ES. 